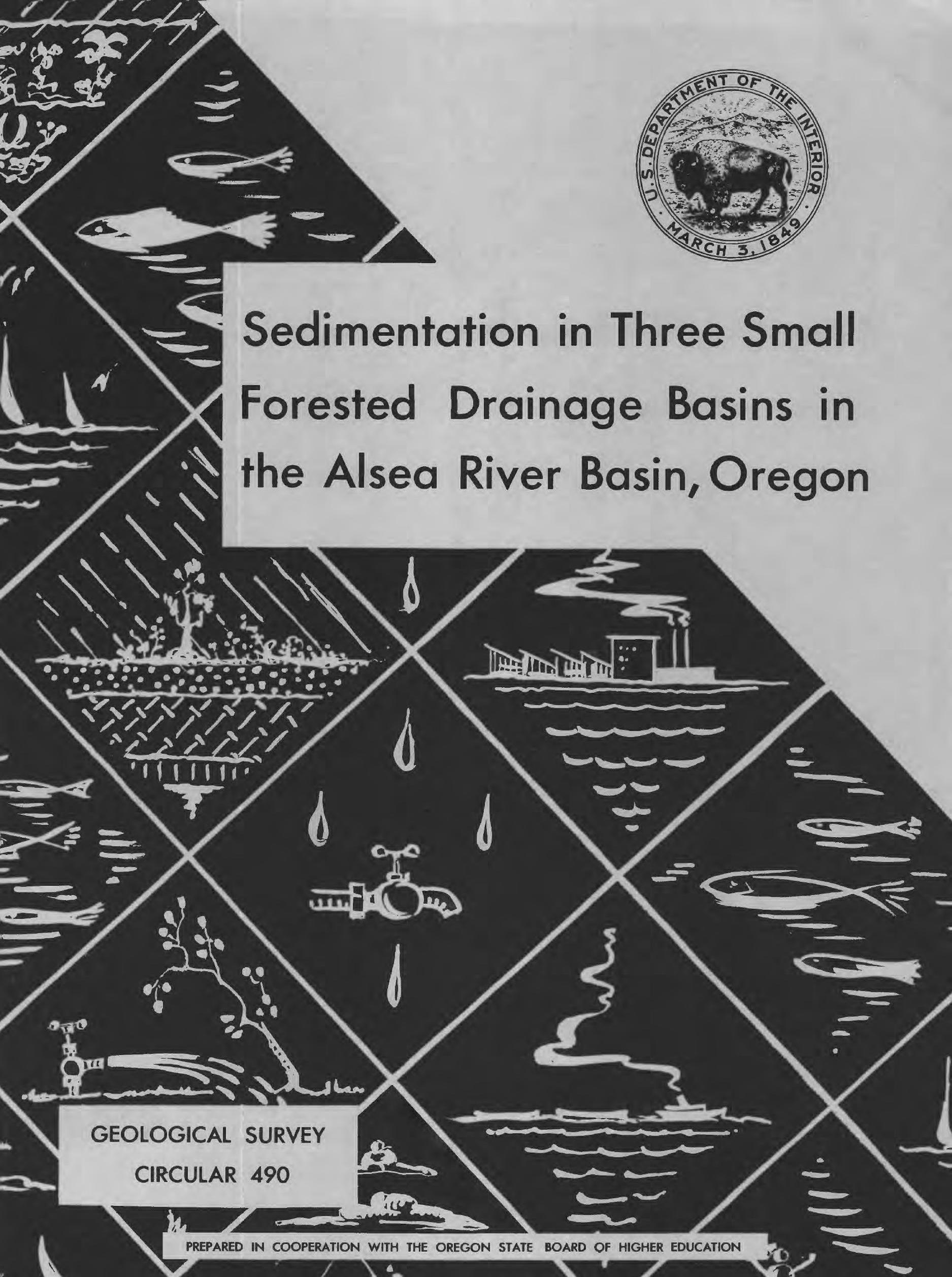




\section{Sedimentation in \\ Three Small Forested Drainage Basins in the Alsea River Basin, Oregon \\ By R. C. Williams}

父

Grological Survey Circular 490

Prepared in cooperation with

the Oregon State Board of Higher Education 
United States Department of the Interior STEWART L. UDALL, SECRETARY

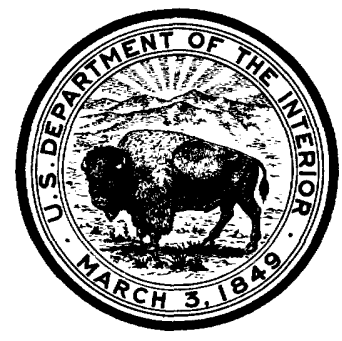

Geological Survey

THOMAS B. NOLAN, DIRECTOR 


\section{- CONTENTS}

\begin{tabular}{|c|c|c|}
\hline \multirow{2}{*}{\multicolumn{3}{|c|}{ Introduction-Continued }} \\
\hline & & \\
\hline Introduction, & 1 & Water and sediment data \\
\hline Purpose and scope & 1 & Fluvial sediment \\
\hline General description of the drainage & & Relations to rainfall and runoff \\
\hline basins & 2 & A freshet period \\
\hline Methods of measurement & 4 & Flow and concentration \\
\hline Rainfall _... & 5 & duration \\
\hline Water discharge & 5 & Water temperature \\
\hline Water temperature & 5 & Summary \\
\hline Suspended-sediment discharge .... & 5 & Literature cited \\
\hline
\end{tabular}

\section{ILLUSTRATIONS}

Figure 1. Map showing location of the study basins

Page

2. Profiles of stream channels

3. Comparison by drainage basin of precipitation, runoff, and suspended-sediment yield for 1960 water year

4. Distribution by month for precipitation, runoff, and suspended-sediment load for 1960 water year.

5. Comparison of hydrologic factors for the Deer Creek basin for the period January 7-13, 1959

6. Streamflow and suspended-sediment concentration duration curves for the streams

\section{TABLES}

Table 1. Monthly rainfall of basins

2. Monthly streamflow and runoff of basins

3. Average monthly maximum and minimum water temperatures

4. Monthly suspended-sediment load.

5. Annual rainfall, runoff, and suspended-sediment 


\title{
Sedimentation in Three Small Forested Drainage Basins in the Alsea River Basin, Oregon
}

\author{
By R. C. Williams
}

\section{ABSTRACT}

A multidiscipline investigation to determine the effects of logging on the ecology of three small forested tributary basins is a part of an overall study of the Alsea River basin in the Coast Range of Oregon. The investigation of these small basins will be to (1) establish pre-logging conditions, (2) determine the effects of different logging methods, and (3) study the rate of recovery after the timber harvest. This report presents results of sedimentation in the basins, Deer and Flynn Creeks and Needle Branch, for the first 2 years of study (1959 and 1960 water years).

Rainfall, runoff, and sediment discharge are seasonal for the Coast Range of western Oregon. About 95 percent of the rainfall and rnnoff occurs during the period October to May, but nearly 100 percent of the suspended-sediment discharge occurs during the same period. For Deer Creek, in the 1960 warer year, 23 percent of the annual suspended-sediment lischarge occurred on 1 day, 58 percent during the 10 days of greatest discharge, and 78 percent during the 38 days of greatest discharge.

Rainfall is practically equal for all three of the basins. The runoff of the Deer and Flynn Creek basins is about equal, but that of the Needle Branch basin averaged 8 percent less.

Sediment yield varies considerably for the three basins. The suspended-sediment yield of the Deer Creek basin is almost twice that of the Needle Branch basin and almost $1 \frac{1}{2}$ times that of the Flynn Creek basin.

Water temperature of the three streams varied only $22^{*} \mathrm{~F}$ during the 2 water years. The greatest variation between streams was $3^{\circ} \mathrm{F}$ in the minimums. Water temperature effect can be neglected in comparing the sediment yields of the basins.

The aquifers of the basins have low storage capacities as illustrated by the very low, late summer flow. A study of a midwinter freshet period for the Deer Creek basin showed that virtually all the rainfall left the basin as runoff within 4 days; the period of significant sediment transport was thus very short.

\section{INTRODUCTION}

\section{PURPOSE AND SCOPE}

The purpose of the overall study is to determine the effects of man's use on the environment of forested drainage basins. The scope of this part of the study is to investigate the effects of environmental changes on the sedimentation of forested drainage basins under natural conditions, under different timber harvesting methods, and during the recovery phase after the timber harvest. This report is the first in a series of data analyses which will follow the progress of the sedimentation investigation. It deals with the first 2 years of the prelogging phase which will last approximately 5 years. The study of all aspects of watershed ecology will span a period of 10 to 15 years.

This investigation is concerned with the sedimentation in three small drainage basins in the Alsea River basin in Oregon. The first phase will be a definition of the undisturbed conditions in each of the three small basins. The second phase will measure the changes in sediment yield as logging progresses in the Deer Creek and Needle Branch basins. The Needle Branch basin will be clear-cut of all timber, whereas the Deer Creek basin will be logged in a staggered cutting pattern. The third phase will cover the rate and extent of recovery of the basins. Sediment yield from these two basins will be compared with that of the Flynn Creek basin, which will remain undistrubed for the entire study as the control or calibration basin. The area studied comprises only a small part of the Alsea River basin, but the findings should have application in other parts of this basin and some application to other forested drainage basins.

Runoff, suspended-sediment discharge, and water temperature are readily measured and provide good indices of drainage-basin environment. This report summarizes the hydrologic data collected during the first 2 years of the study and points out some of the relationships between basin environment and climate. 
The overall study in the Alsea River basin is a multidiscipline examination of drainage basin ecology. The major parts of this comprehensive study are: (1) a soil-vegetation survey designed to inventory the soils and vegetation of the entire Alsea River basin and to provide a base for research in drainagebasin management, (2) a water resource survey of the major tributaries of the Alsea River designed to provide abase for research in drainage-basin management and water use, (3) a study of the effect of logging upon the physical and biotic resources of small streams, and (4) the study of the migration and production of salmonoid fish in selected streams of the basin. The overall study is coordinated by the Oregon Agricultural Experiment Station under the Oregon State Board of Higher Education. The participants in this study include the U.S. Geological Survey, U.S. Forest Service, Bureau of Land Management, Soil Conservation Service, the Soils Department and School of Forestry of Oregon State University, Georgia-Pacific Corp., and the Oregon State Game Commission.

\section{GENERAL DESCRIPTION OF THE DRAINAGE BASINS}

The Alsea River rises on Marys Peak (elev. 4,097 feet) and drains about 473 square miles of the timber-covered Coast Range of Oregon before emptying into the Pacific Ocean at Waldport. The drainage basins being used for the sedimentation study comprise a very small part of the Alsea River basin. Deer Creek has a drainage area of 1.20 square miles; Flynn Creek has a drainage area of 0.84 square mile; Needle Branch, the smallest of the three streams, has a drainage area of only 0.32 square mile. (See fig. 1.)

The altitude of these three small basins ranges from about 1,600 feet at the highest point of the Deer Creek hydrographic divide to about 430 feet at the Needle Branch confluence with Drift Creek. The drainage valleys are V-shaped and have moderate to steep side slopes. A canopy of Douglas fir intermixed with alder covers almost all of the area and intercepts much of the rainfall. A very heavy growth of understory vegetation covers virtually all of the drainage basins, giving good natural protection against erosion of the fine-grained surface soils. Much timber debris in the valley bottoms forms natural settling basins in places where it retards the flow of the streams. Little meandering occurs, and the streambeds are generally well armored with fine to coarse gravel.

The area is underlain by the Burpee Formation of middle Eocene age, which may be contemporary with the Tyee Formation to the south (Vokes and others, 1949): The Burpee Formation consists of a thick sequence of micaceous sandstones interbedded with mudstones and siltstones. It is characterized in the study area by moderate dip slopes and heavy soil mantle, and by steep slopes and a shallow, sandy, soil cover where beds of sandstone are exposed. The variability of the slopes and soils causes much of the variability in the sediment yield from these basins.

The mild humid climate of the area is typical of the coastal region of western Oregon. About 90 inches of rainfall is recorded annually, and most of it occurs during the months from October to May. Temperatures generally range between $20^{\circ} \mathrm{F}$ and $90^{\circ} \mathrm{F}$, with a mean of about $51^{\circ} \mathrm{F}$.

The environments of the three basins appear to be very similar because all three are characterized by dense, virgin forest. The communities formed by the principal understory vegetation-such as sword ferns, salmonberry, and vine maple-vary greatly from place to place, but the density of growth varies little from basin to basin. However, the proportions of the Douglas fir and alder overstory vary appreciably. About 60 percent of the overstory in the Deer and Flynn Creek basins is alder, whereas the overstory of the Needle Branch basin is only about 20 percent alder.

There are some differences in the geomorphology of the threebasins. Surveys made by Oregon Agricultural Experiment Station personnel using an altimeter show that the basins have dissimilar gradients. The data from these surveys are plotted in figure 2.

Deer Creek basin has drainage slopes averaging about 40 percent and characteristically thinner mantles of sandy soil (C. T. Dyrness, U.S. Forest Service, written communication, 1962). The drainage pattern of this basin is more fully developed than that for the other two basins; thus the runoff collects more rapidly and creates a greater sediment erosion potential in Deer Creek 


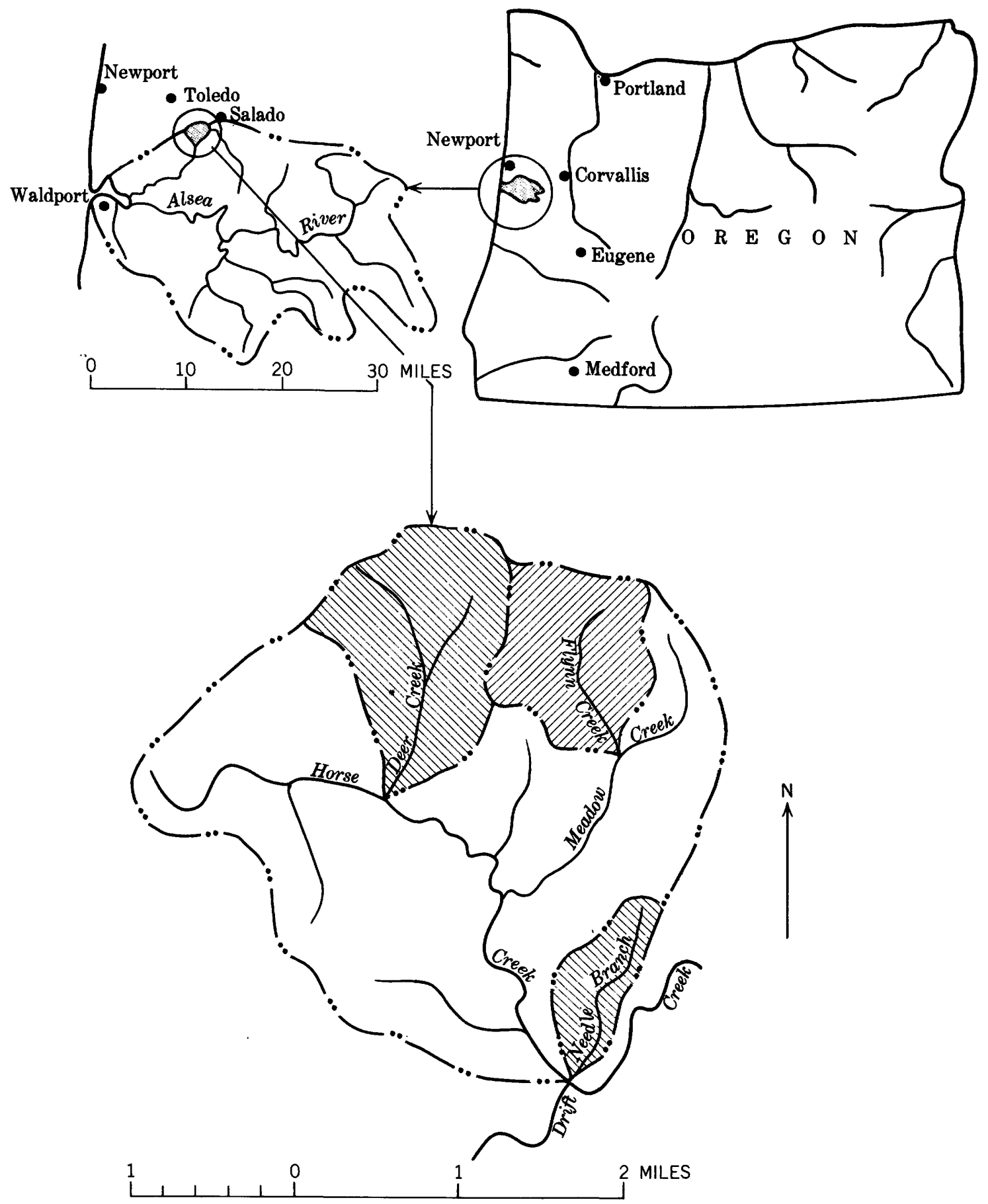

Figure 1. - Map showing location of the study basins in the Alsea River basin, Oregon. 


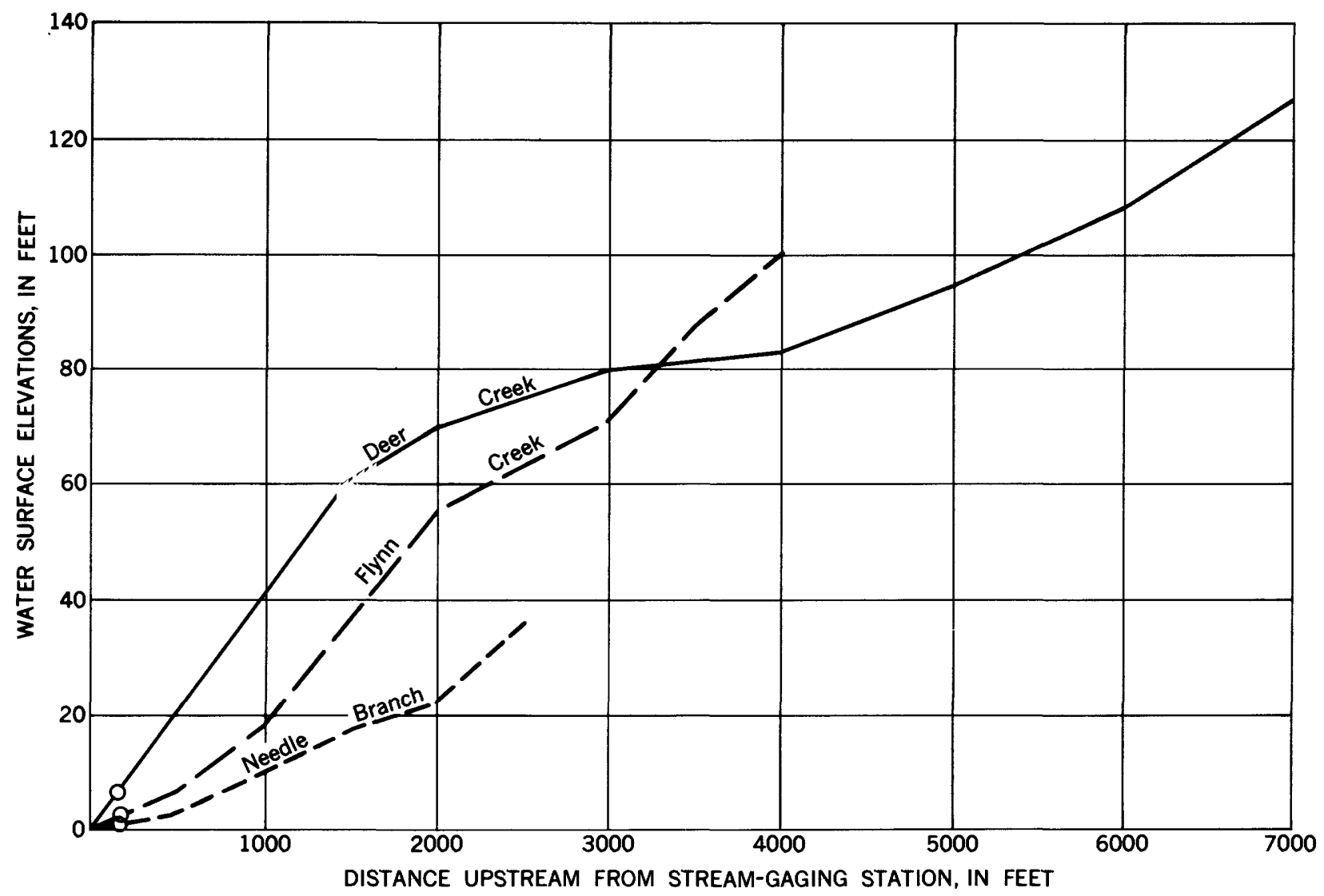

Figure 2.-Profile of stream channels. $O$, sediment sampling site.

basin. Some of the tributary channels in the basin show signs of active erosion; probably much of the sediment yield of the basin is derived from these tributaries.

The drainage slopes of Flynn Creek basin average about 34 percent. Much of the basin is on a moderate dip slope of the Burpee sandstone beds where there is generally a thick layer of fine soil. Water is temporarily stored in surface depressions and as soil moisture on the relatively flat dip slopes during freshet periods. The drainage pattern is not well defined, and the moderate runoff from these areas lacks the energy for largescale erosion of the tributary channels.

The Needle Branch basin has drainage slopes averaging about 37 percent. The heavy Douglas fir canopy and the relatively flat stream gradient combine to limit the runoff and sediment yield from the watershed. Thirty-two acres in the headwaters were logged off 7 to 10 years ago. The understory vegetation, however, has regrown to the ex- tent that prelogging conditions seem to prevail as indicated by runoff and sediment yield.

The environment of the basins to date (1961) has been altered only by the structures and trails made for this study. Minor adjustments in the stream gradient in the vicinity of the concrete control weirs and fish traps will continue for some time, but these changes are local in nature and should have little effect on the overall environment.

The various environmental factors affecting sediment yield are complicated and inseparable. A change in one will produce a change in the others. When logging or other uses of these basins begins, the Needle Branch basin could have a higher sediment yield than the Deer Creek basin.

\section{METHODS OF MEASUREMENT}

Often long-term sediment data must be obtained or a statistical approach must be used to establish relationships of sediment yield 
to the other hydrologic and environmental parameters. It is intended, during this study, to collect and use comprehensive hydrologic data to analyze these relationships. The material presented in this preliminary report is based on water and suspended-sediment data collected during the 1959 and 1960 water years. Terms used herein are those used by the U.S. Geological Survey in the annual series of Water-Supply Papers "Quality of Surface Waters of the United States."

Field surveys of the sediment deposits behind the concrete control weirs have been made to determine the amount and character of these sediments. The results of the surveys and particle-size analyses are incomplete at this time; they will be included in subsequent reports.

\section{RAINFALL}

Continuous records of rainfall are available for sites just downstream from the gaging stations in each of the three basins by the Oregon Agricultural Experiment Station at Oregon State University. The gages, USWB 8-inch recording types, are so located as to be affected as little as possible by wind currents and vegetal cover. A summary of monthly rainfall for the period January 1959 to September 1960 for these three sites is given in table 1. The records for these and other sites in the Alsea River basin have been published by Chapman and others (1961).

\section{WATER DISCHARGE}

Stream-gaging stations near the mouth of the streams are used to determine water discharge from the basins. These stations consist of a conventional gage house and well that are equipped with continuous water-stage recorders. Controls for stabilizing ratings of water discharge to gage height are provided by a concrete weir at each station.

\section{WATER TEMPERATURES}

A continuous record of water temperature for each stream is obtained by an attachment on the water-stage recorders. The sensing element is located at the end of the gagehouse well intake pipe in the pool behind the weir. Daily maximum and minimum temperatures are determined from these records. :

\section{SUSPENDED-SEDIMENT DISCHARGE}

During the period of record included in this report, the suspended-sediment load was measured at sites just upstream from the stream-gaging stations.

The streambed at the Deer Creek sampling site consists of angular rock fragments, whereas the beds at the Flynn Creek and Needle Branch sites consist of sand and fine gravel. Higher velocities at the Deer Creek site cause greater turbulence which probably results in a larger load of suspended sand

Table 1.-Monthly rainfall of basins, in inches by water year

\begin{tabular}{|c|c|c|c|c|c|c|}
\hline \multirow{2}{*}{ Month } & \multicolumn{2}{|c|}{ Deer Creek } & \multicolumn{2}{|c|}{ Flynn Creek } & \multicolumn{2}{|c|}{ Needle Branch } \\
\hline & 1959 & 1960 & 1959 & 1960 & 1959 & 1960 \\
\hline October & - & 8.73 & & 7.77 & ------ & 9.43 \\
\hline November & $----n-$ & 6.59 & & 5.95 & $\ldots \ldots$ & 6.96 \\
\hline December & $-\ldots-\ldots$ & 9.26 & $-\ldots . .-$ & 8.16 & - n... & 8.95 \\
\hline January_. & 23.00 & 9.81 & 21.27 & 10.29 & 25.19 & 11.00 \\
\hline February & 12.00 & 18.16 & 10.46 & 18.16 & 12.17 & 17.71 \\
\hline March & 10.47 & 12.77 & 9.82 & 12.77 & 11.33 & 13.65 \\
\hline April & 4.83 & 9.04 & 4.70 & 8.32 & 4.95 & 9.24 \\
\hline May & 5.70 & 10.53 & 5.22 & 9.84 & 6.30 & 9.19 \\
\hline June & 3.62 & 1.20 & 3.37 & 1.08 & 3.90 & .95 \\
\hline July & .65 & .03 & .69 & .00 & .78 & .00 \\
\hline August & .60 & 2.37 & .56 & 2.14 & .52 & 2.21 \\
\hline September & 11.49 & .36 & 11.26 & .29 & 13.12 & .41 \\
\hline Total & 72.36 & 88.85 & 67.35 & 84.77 & 78.26 & 89.70 \\
\hline
\end{tabular}


than that carried by the other two streams. Some sand and gravel move past the sampling sites as bedload. A major part of the bedload and some of the suspended sediment have been deposited in the backwater pools of the concrete control weirs. The rate of deposition gradually diminished until the end of the 1960 water year when the amount of sediment being retained in the pools behind the weirs was only a small part of the total sediment load. All the sampling sites were subsequently moved to the control weirs where virtually the total sediment load can be sampled and the yield of the basins can be compared more accurately.

Surveys were made at selected transects of the channel upstream from the weirs to determine the volume of the deposits. Random core samples were obtained to determine the specific weight and the particle-size distribution of the material in the deposits. This procedure will be repeated yearly to evaluate the amount and character of this part of the sediment load. These values will then be reported in yearly increments to permit the determination of the annual total load.

The suspended-sediment samples were collected at midstream with DH-48 depth-integrating samplers at time intervals ranging from one or two times a week during periods of low flow to as often as four times a day during periods of high flow. These midstream samples were considered to be representative of stream concentration because of the narrow, turbulent nature of the streams.

For some periods when no samples were collected, daily loads of suspended sediment were estimated on the basis of water discharge, sediment concentrations observed immediately preceding and following the periods, and suspended-sediment loads for other periods of similar discharge. Sediment loads from one or both of the other two stations and weather conditions were used to make these estimates.

\section{WATER AND SEDIMENT DATA}

Complete tables of water and sediment data summarized for this report are published in U.S. Geological Survey Water-Supply Papers. These reports also contain discussions of istandard methods and terms used but not fully defined in this report. Daily stream- flow data for the period covered have been published in Water-Supply Papers 1638 and 1718. These data are summarized in table 2. Data on daily extremes of water temperature, daily suspended-sediment loads, and sediment particle-size analyses will be published in Water-Supply Papers 1745 and 1815. Monthly averages of the daily water temperature extremes are summarized in table 3. A summary of monthly suspendedsediment loads is given in table 4 .

\section{FLUVIAL SEDIMENT}

\section{RELATIONS TO RAINFALL AND RUNOFF}

Data on rainfall, runoff, and suspendedsediment transport collected during the 1959 and 1960 water years are summarized in table 5. The recorded rainfall data are for the period January 1, 1959, to September 30, 1960. All other data are for November 20 , 1958 , to September 30, 1960. The data were tabulated in this form to compare individual items for corresponding periods of time. The true relation of the rainfall to runoff may not actually be so close as the table indicates because rainfall was recorded at only one point near the mouths of the streams. The relation might be different if rainfall had also been recorded at upstream sites.

Table 5 suggests that the rainfall for the Needle Branch drainage basin is greater than that for Deer and Flynn Creek basins. Shortterm precipitation records may be misleading, however, because studies have shown that considerable differences are sometimes recorded even by adjacent gages (Court, 1960; Mead, 1950). No significant difference in the average annual rainfall of the three basins is expected because of the close proximity of the basins, their alinement, and their similar altitudes. During the short period of record no large differences have occurred in the amount and distribution of the rainfall at the three rain gages used during this study.

As table 5 shows, the runoff for Deer and Flynn Creek basins was nearly equal for each of the 2 years of study, but that for Needle Branch basin averaged only 92 percent of the average for the other two. Part of the difference can probably be explained by the difference in the overstory vegetation of the basins. As pointed out earlier, the Needle Branch basin has about 80 percent Douglas fir in the overstory compared to 


\begin{tabular}{|c|c|c|c|c|c|c|c|}
\hline \multirow{5}{*}{ 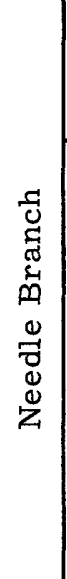 } & 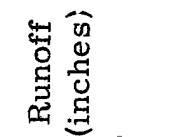 & 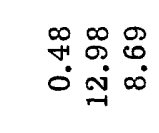 & 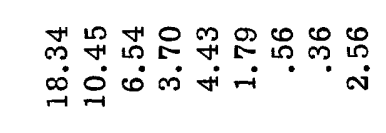 & $\begin{array}{l}\infty \\
\infty \\
\dot{0}\end{array}$ & 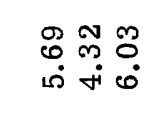 & 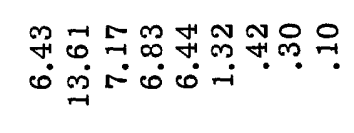 & $\begin{array}{l}\dddot{0} \\
\infty \\
\infty\end{array}$ \\
\hline & 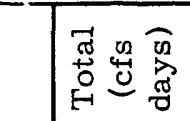 & 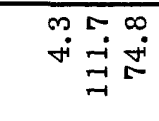 & 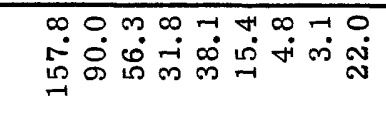 & $\begin{array}{l}-1 \\
0 \\
\\
0\end{array}$ & 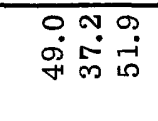 & 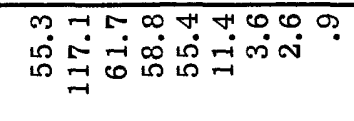 & 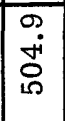 \\
\hline & 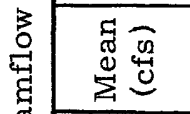 & 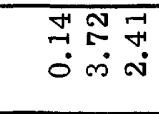 & 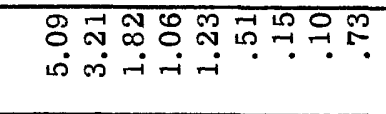 & $\stackrel{5}{5}$ & 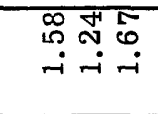 & 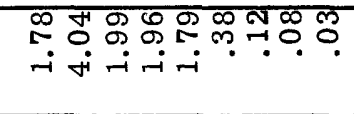 & क् \\
\hline & 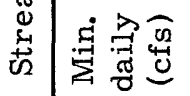 & 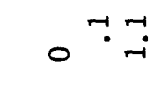 & 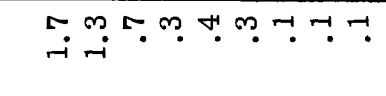 & 0 & $0^{10} \cdot 5$ & 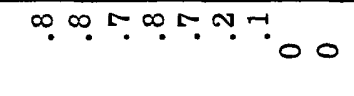 & 0 \\
\hline & 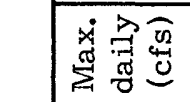 & 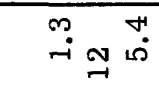 & $\stackrel{\infty}{\infty} \stackrel{\infty}{\sim} \stackrel{+}{+} \dot{\sim} \sim$ & $\stackrel{\infty}{\rightarrow}$ & 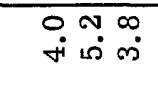 & 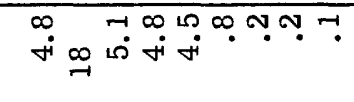 & $\stackrel{\infty}{\sim}$ \\
\hline \multirow{5}{*}{ 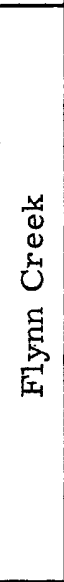 } & 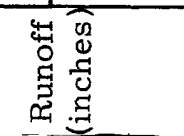 & 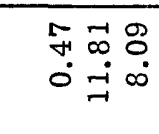 & 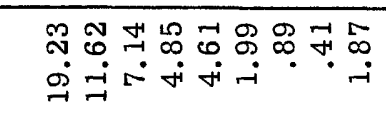 & \begin{tabular}{l}
$\infty$ \\
$\infty$ \\
\multirow{2}{N}{}
\end{tabular} & 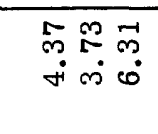 & 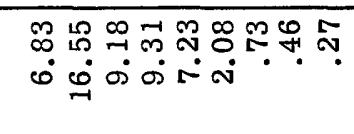 & 造 \\
\hline & 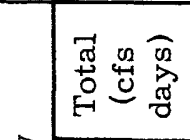 & 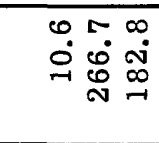 & 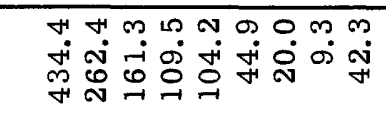 & $\begin{array}{l}+1 \\
\infty \\
+ \\
0 \\
0 \\
-1\end{array}$ & 下年 & 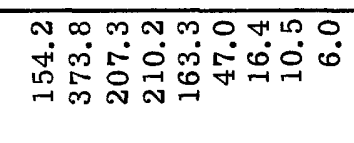 & -1 \\
\hline & 宽 & 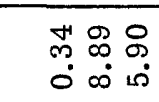 & 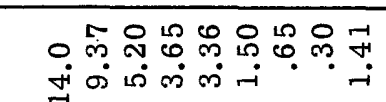 & ஸै & 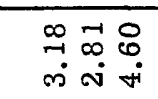 & 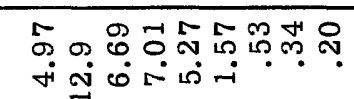 & $\underset{4}{M}$ \\
\hline & 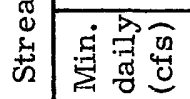 & $\ddot{0} \ddot{m}$ & 身 & $\ddot{0}$ & 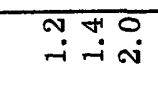 & 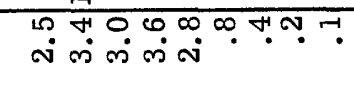 & $\ddot{0}$ \\
\hline & 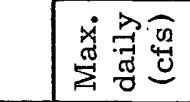 & जi & 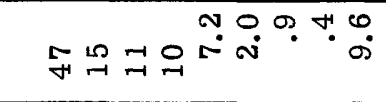 & F & 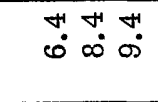 & 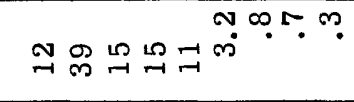 & శ్లి \\
\hline \multirow{5}{*}{ 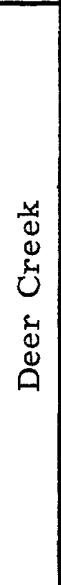 } & 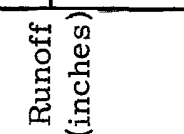 & $\begin{array}{lll}m & m & m \\
0 & \sigma & \sharp \\
0 & \dot{t} & \infty\end{array}$ & 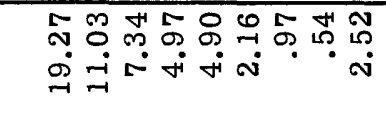 & $\begin{array}{l}\dot{0} \\
\dot{0}\end{array}$ & 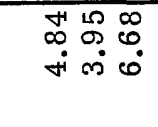 & 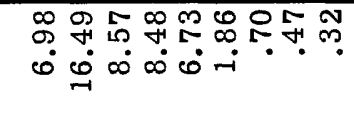 & $\begin{array}{l}5 \\
0 \\
0 \\
0\end{array}$ \\
\hline & 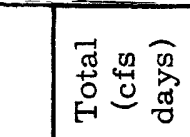 & 함 & 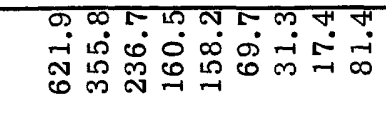 & 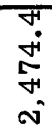 & 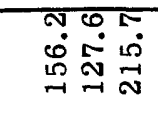 & 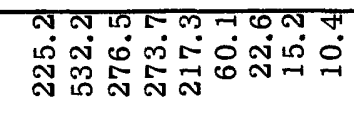 & $\begin{array}{l}5 \\
\text { Nं } \\
\text { mे } \\
\text { N }\end{array}$ \\
\hline & 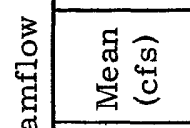 & $\begin{array}{l}\infty_{0}^{\infty} \\
0 \\
0 \\
0 \\
0\end{array}$ & 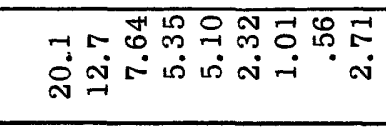 & $\begin{array}{l}\infty \\
\stackrel{\infty}{T} \\
0\end{array}$ & 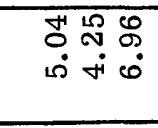 & 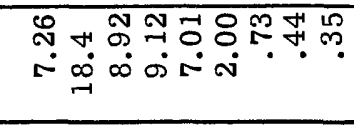 & $\begin{array}{l}\mathscr{M} \\
\infty \\
\infty\end{array}$ \\
\hline & 离 & $\ddot{0} \cdot \stackrel{\infty}{+\infty}$ & 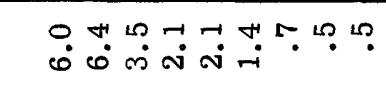 & $\ddot{0}$ & 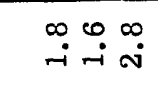 & 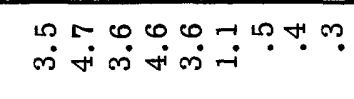 & $\ddot{0}$ \\
\hline & 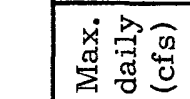 & $m$ & ธี兀 & 5 & 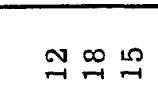 & 晃 & $\overrightarrow{0}$ \\
\hline & 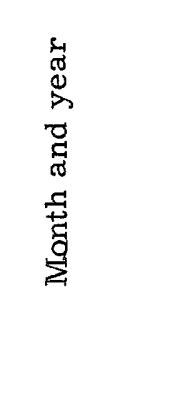 & $\begin{array}{l} \\
\\
\end{array}$ & 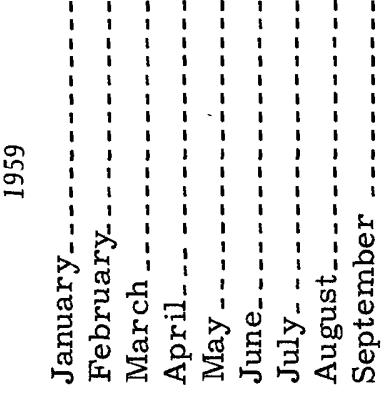 & 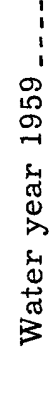 & 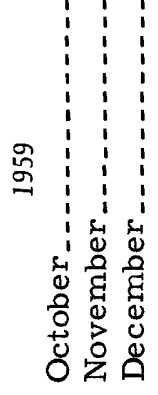 & 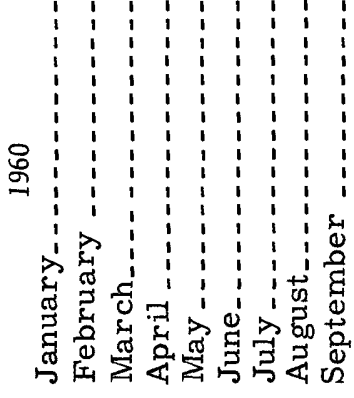 & 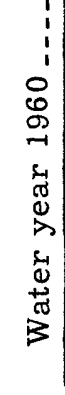 \\
\hline
\end{tabular}


Table 3.-Average monthly maximum and minimum water temperatures, in degrees Fahrenheit by water year

\begin{tabular}{|c|c|c|c|c|c|c|c|c|c|c|c|c|}
\hline \multirow{3}{*}{ Month } & \multicolumn{4}{|c|}{ Deer Creek } & \multicolumn{4}{|c|}{ Flynn Creek } & \multicolumn{4}{|c|}{ Needle Branch } \\
\hline & \multicolumn{2}{|c|}{1959} & \multicolumn{2}{|c|}{1960} & \multicolumn{2}{|c|}{1959} & \multicolumn{2}{|c|}{1960} & \multicolumn{2}{|c|}{1959} & \multicolumn{2}{|c|}{1960} \\
\hline & Max. & Min. & Max. & Min. & Max: & Min. & Max. & Min. & Max. & Min. & Max. & Min. \\
\hline October & 54 & 52 & 50 & 49 & 52 & 51 & 51 & 50 & 53 & 52 & 51 & 51 \\
\hline November & 49 & 48 & 46 & 45 & 49 & 48 & 48 & 47 & 49 & 48 & 48 & 46 \\
\hline February _. & 47 & 46 & 46 & 45 & 47 & 46 & 47 & 47 & 47 & 46 & 46 & 46 \\
\hline March & 48 & 47 & 46 & 45 & 48 & 47 & 48 & 46 & 46 & 46 & 47 & 46 \\
\hline April $\ldots \ldots$ & 50 & 48 & 49 & 47 & 49 & 47 & 49 & 48 & 49 & 47 & 49 & 48 \\
\hline May _... & 49 & 48 & 49 & 48 & 50 & 48 & 50 & 49 & 49 & 48 & 49 & 49 \\
\hline June & 51 & 50 & 53 & 50 & 52 & 51 & 53 & 51 & 51 & 50 & 53 & 51 \\
\hline Average & 50 & 49 & 50 & 48 & 50 & 49 & 50 & 49 & 50 & 49 & 50 & 49 \\
\hline
\end{tabular}

Table 4. -Monthly suspended-sediment loads, in tons

\begin{tabular}{|c|c|c|c|c|c|c|}
\hline \multirow{2}{*}{ Month } & \multicolumn{3}{|c|}{1959 Water year } & \multicolumn{3}{|c|}{1960 Water year } \\
\hline & Deer Creek & Flynn Creek & Needle Branch & Deer Creek & Flynn Creek & Needle Branch \\
\hline $\begin{array}{l}\text { October } \\
\text { November. } \\
\text { December } \\
\text { January } \\
\text { February } \\
\text { March } \\
\text { April } \\
\text { May } \\
\text { June. } \\
\text { July } \\
\text { August_.- } \\
\text { September }\end{array}$ & $\begin{array}{r}7.1 \\
5.2 \\
62.0 \\
7.1 \\
2.8 \\
1.5 \\
1.7 \\
.8 \\
.3 \\
.1 \\
1.1\end{array}$ & $\begin{array}{r}12.4 \\
3.2 \\
39.1 \\
4.3 \\
1.4 \\
1.1 \\
.8 \\
\\
\text { (2) } \\
\text { (2) } \\
\end{array}$ & $\begin{array}{rr}-1.4 \\
\\
10.3 \\
1.3 \\
\\
& .7 \\
& .2 \\
& .3 \\
(2) & \\
(2) & \\
(2) & \\
& .4\end{array}$ & $\begin{array}{rr} & 1.7 \\
& 4.9 \\
& 5.6 \\
& 7.0 \\
& 53.3 \\
& 6.6 \\
& 7.3 \\
& 3.3 \\
& .4 \\
& \\
\text { (2) } & \\
\text { (2) } & \\
\text { (2) } & \end{array}$ & $\begin{array}{rr} & 0.7 \\
& .9 \\
& 1.2 \\
& 3.3 \\
& 27.0 \\
& 2.9 \\
& 2.3 \\
& \\
& .3 \\
\text { (2) } & \\
\text { (2) } & \\
\text { (2) } & \\
\text { (2) } & \end{array}$ & $\begin{array}{lr} & 0.2 \\
& .3 \\
& .2 \\
& .5 \\
& 8.1 \\
& .6 \\
& .4 \\
& .3 \\
& \\
& \\
& \\
& \\
& \\
\text { (2) } & \\
\text { (2) } & \\
\text { (2) } & \end{array}$ \\
\hline Total _- & ${ }^{3} 89.7$ & ${ }^{3} 53.1$ & 315.5 & 90.1 & 38.7 & 10.6 \\
\hline
\end{tabular}

${ }^{1}$ Does not include sediment load for Nov. 1-19.

${ }^{2}$ Less than 0.050 ton.

${ }^{3}$ Does not include sediment load for October 1 to November $19,1958$. 


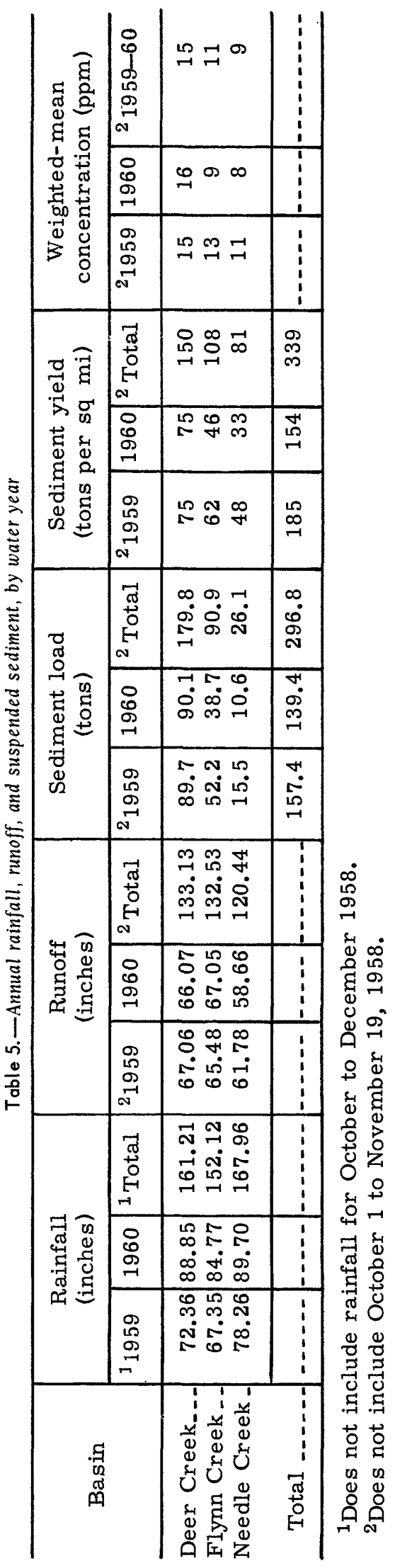

about 40 percent in the other two basins (C. T. Dyrness, U.S. Forest Service, written communication, 1961). The fir intercepts more of the water during the heavy rainfall period because the alder has no leaves then. Another possible explanation of the difference could be the loss due to subsurface flow from the basin, either through the tilted sandstone beds or through the alluvium of the valley mouth.

The suspended-sediment loads of the three streams-for November 1958 to September 1960-vary considerably, as would be expected from the relative size of their drainage basins. The drainage area of Deer Creek is 3.8 times that of Needle Branch, but the sediment load was 6.9 times as large. Flynn Creek has 2.6 times the drainage area, but transported 3.5 times more sediment than Needle Branch.

A better comparison of the three basins can be made by dividing the annual suspendedsediment load of each stream by the area of the drainage basin to obtain the suspendedsediment yield. These unit area values (table 5) show that the suspended-sediment yield for the Deer Creek basin for November 1958 to September 1960 was 1.4 times that for the Flynn Creek basin and 1.9 times that for the Needle Branch basin.

The 1960 water year was the only full year for which records of rainfall, runoff, and suspended-sediment yield were available. The bar graph presented in figure 3 compares the relationships between precipitation, runoff, and suspended-sediment yield for 1960 . For almost equal values of recorded rainfall, the runoff values for Deer and Flynn Creek basins were almost equal, but the runoff for the Needle Branch basin was only 88 percent of the average of the other two. The ratios of runoff to rainfall are $0.74,0.79$, and 0.65 , respectively, for the Deer Creek, Flynn Creek, and Needle Branch basins. Sediment yields for the 1-year period reflect differences almost the same as those for the November 1958 to September 1960 period. Deer Creek basin has 1.6 times the yield of the Flynn Creek basin and 2.3 times that of Needle Branch basin.

Another comparison can be made of the sediment-transport characteristics of the three basins by using the weighted-mean concentration. Values of this index were 


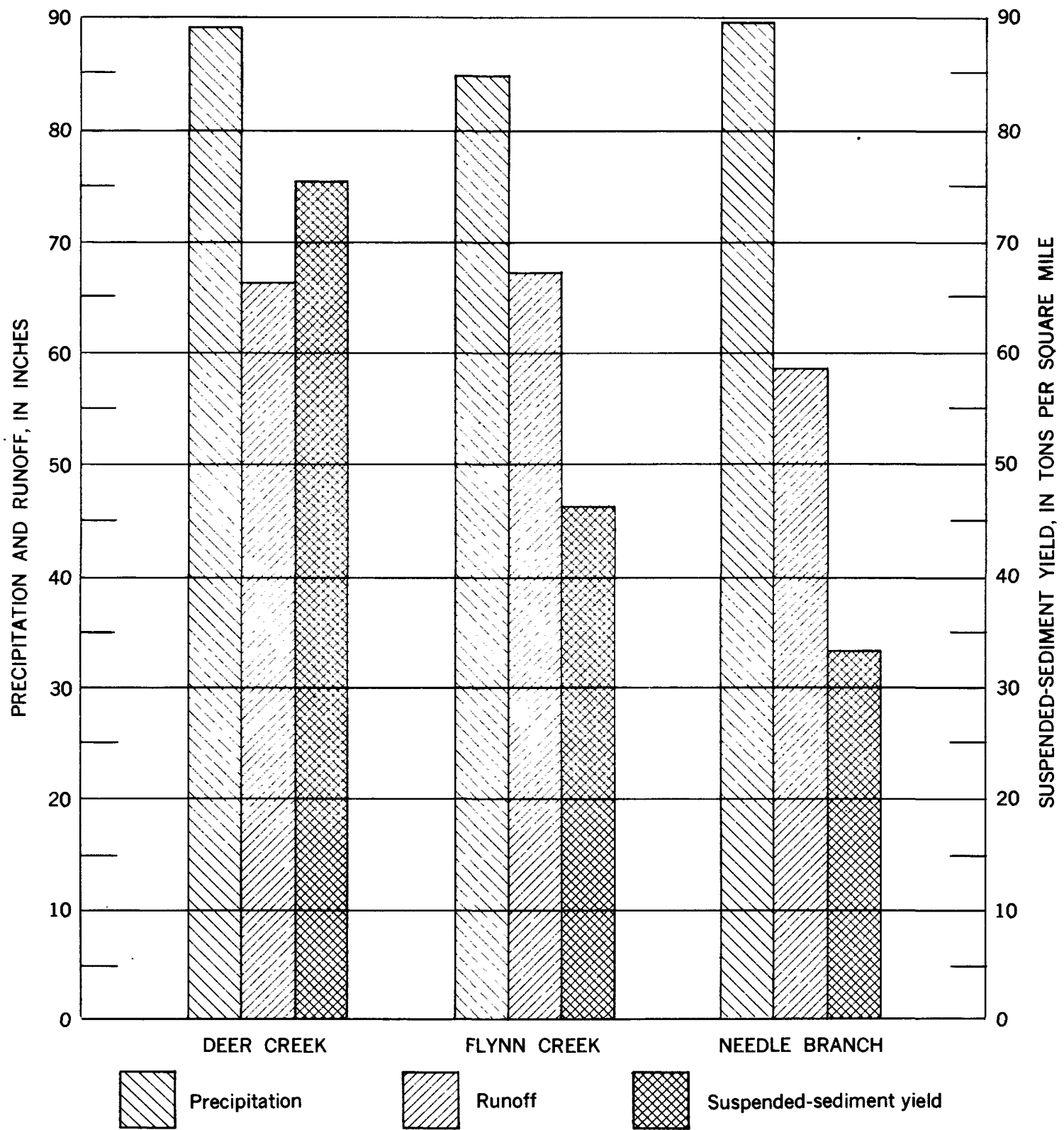

Figure 3. - Comparison by drainage basin of precipitation, runoff, and suspended-sediment yield for 1960 water year.

computed (table 5) for the period November 20,1958 , to September 30, 1959, for the 1960 water year, and for November 20, 1958 to September 30,1960. A comparison of these values for the three basins again emphasizes the greater amount of sediment transported by Deer Creek.

A small part of the differences in sedimenttransport rates may be due to differences in the turbulence at the individual sampling sites. As shown in figure 2, the gradient where samples were obtained on Deer Creek is steeper than the gradients where samples were obtained for the other two streams. Total load computation to be presented in future reports will provide adequate data for study of this item.

The weighted-mean concentration is also useful for comparing the water dischargesediment load relationship for a period of years. Because the data for the missing period October 1 to November 19 of the 1959 water year would have little effect on the weighted-mean concentration of the streams, values computed for the rest of the year can be compared with the 1960 values. This 
comparison shows that the sediment concentration of these streams was nearly the same for each of the 2 years of record. Little change can be expected as long as the streams remain under virgin-forest conditions, but changes in the environment of the basin will most likely be reflected by changes in the weighted-mean concentrations.

The time distribution of precipitation, runoff, and sediment load has vital importance in the study of the hydrologic environment of these drainage basins. The monthly distribution of precipitation, runoff, and suspendedsediment load is given for each drainage basin for the 1960 water year in figure 4. About 95 precent of the precipitation and runoff occurs during the period October to May, but nearly 100 percent of the sediment discharge occurs during the same period. During the 1960 water year, almost two-thirds of the total annual suspended-sediment discharge from the three drainage basins occurred during February. A further breakdown for Deer Creek-the largest carrier-shows that 23 percent of the annual suspended-sediment discharge occurred during 1 day, 58 percent during the 10 days of greatest discharge, and 78 percent during the 38 days of greatest discharge. Thus almost all the sediment discharge of these undisturbed forested watersheds occurs during the relatively few days of freshet activity.

\section{A FRESHET PERIOD}

Because most of the sediment discharge occurs during freshet periods, it is appropriate to study one such interval. The absence of clear definition of the variations of sediment concentration for freshet periods precludes a comprehensive comparison of the drainage basins. The period January 713,1959 , was selected for a study of a freshet in the Deer Creek basin. Definition of the suspended-sediment concentration for the period was fair, and data on rainfall and runoff were available. Data on rainfall intensity, rate of runoff, suspended-sediment concentration, suspended-sediment discharge, and water discharge for the above period are presented in graphic form in figure 5. For general comparison with the hydrologic relationships of other freshet periods for all three basins, all quantities are plotted on a per unit area basis. Water discharge is plotted in cubic feet per second per square mile in the upper graph for better comparison with concentration and suspended-sediment discharge. The suspended-sediment discharge peak closely coincides with the water-discharge peak. During the logging phase, the concentrations may be higher and may thereby have more influence on the shape of the suspended-sediment discharge graph.

Figure 5 shows that rainfall intensity has little effect on sediment discharge. In densely forested areas, such as these drainage basins, there is limited opportunity for the raindrops to reach the soil mantle and to loosen particles by impact. Sediment discharge is influenced by rainfall intensity in these small basins to the degree to which the rainfall determines the magnitude and duration of the runoff peak.

The disposition of the rainfall that leaves the basin as runoff can be studied by means of the graphs presented in figure 5 . In the lower half of the figure, water discharge (in cubic feet per second) has been converted to rate of runoff (in inches per hour) for direct comparison with rainfall intensity. On the rate-of-runoff graph a smooth curve was used between the computed plots, but because of the necessity of computing numerous values for definition, a graph of average rainfall intensity was used. The rainfall intensities changed rather suddenly, and a good average value could be obtained between major breaks of the mass-rainfall curve. These average values were plotted as straight lines for the periods they represent. If a period of time is considered, rate of runoff and rainfall intensity become inches of depth on the drainage area, and therefore, the area under a segment of either graph represents a volume. Because both are plotted on the same scale, the runoff-storage budget can be approximated for any period of time by using the lower half of figure 5. The amount represented by the area between the two graphs above the rateof-runoff graph is stored or lost to the atmosphere, and the amount represented by the area between the two graphs below the rateof-runoff graphs is taken from storage. If a period is chosen between times when surface runoff is depleted, the amount of water contributed to or taken from storage can be approximated for a particular period of time. It must be assumed that recorded rainfall equals actual rainfall and that average rainfall intensities approximate instantaneous values. The daily rainfall for January 7-13 was computed by accumulating the products of the average rainfall intensity and the 


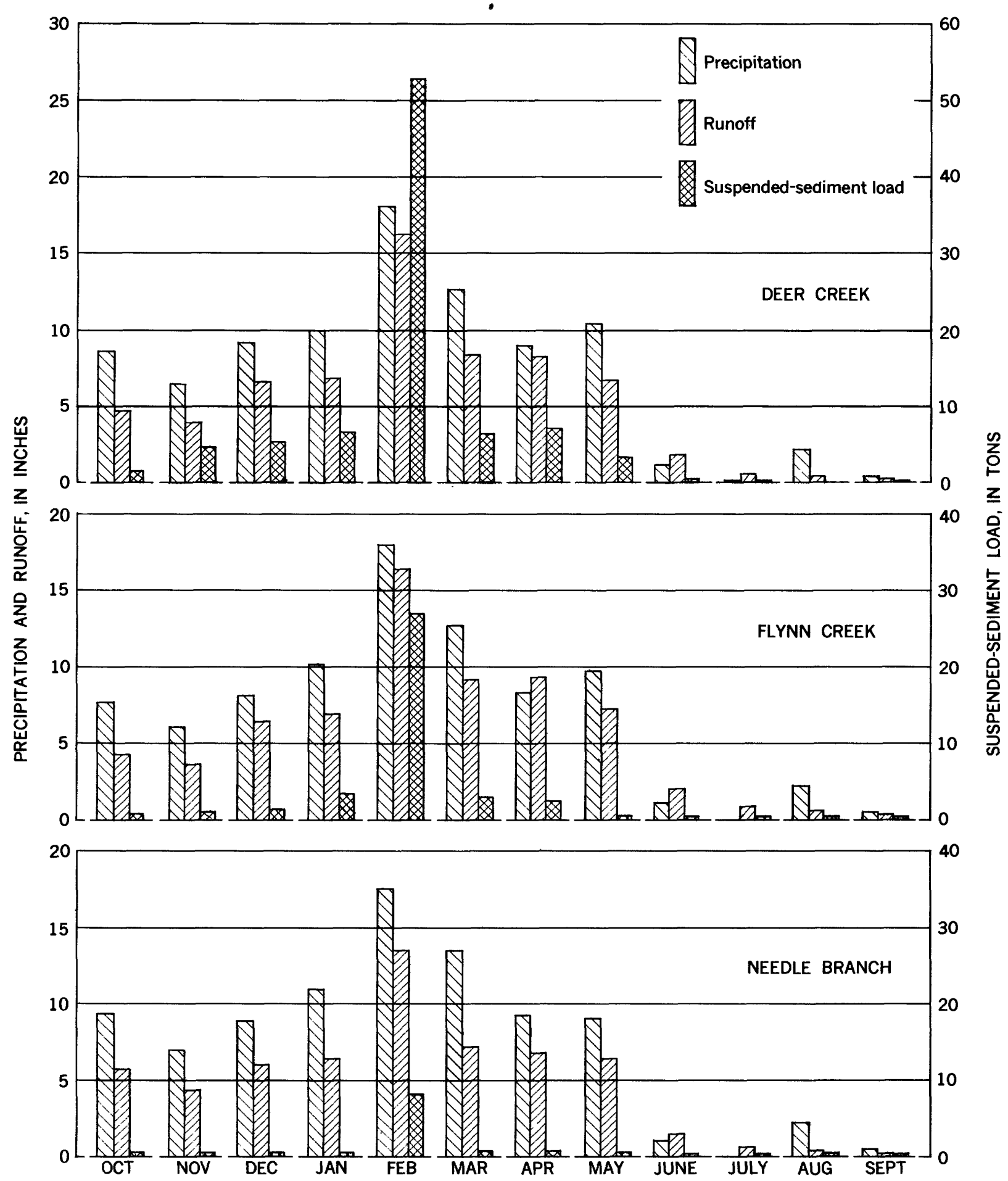

Figure 4. -Distribution by month for precipitation, runoff, and suspended-sediment yield for 1960 water year. 


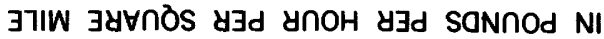
'J5Y甘HOSIO INJWIOJS-OJONJdSOS

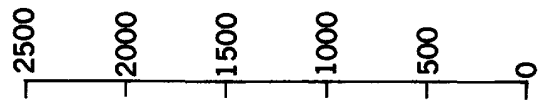

NOI7רIW YJd SLU甘d NI 'NOILVYINJJNOJ

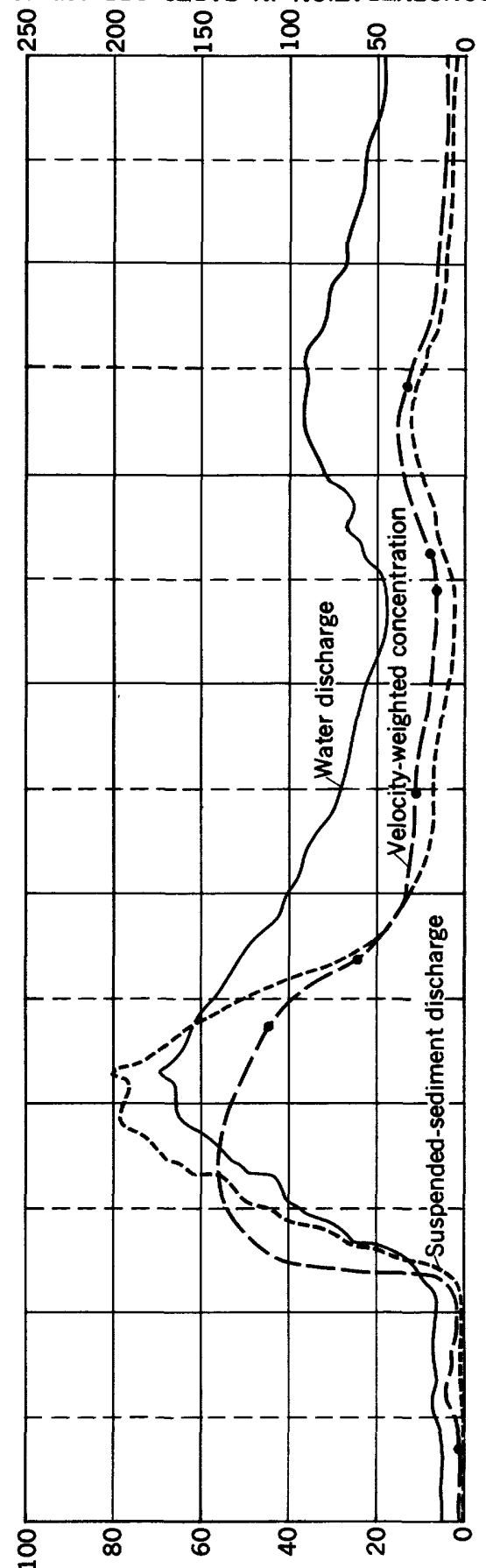

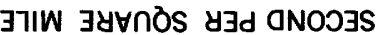

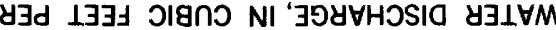
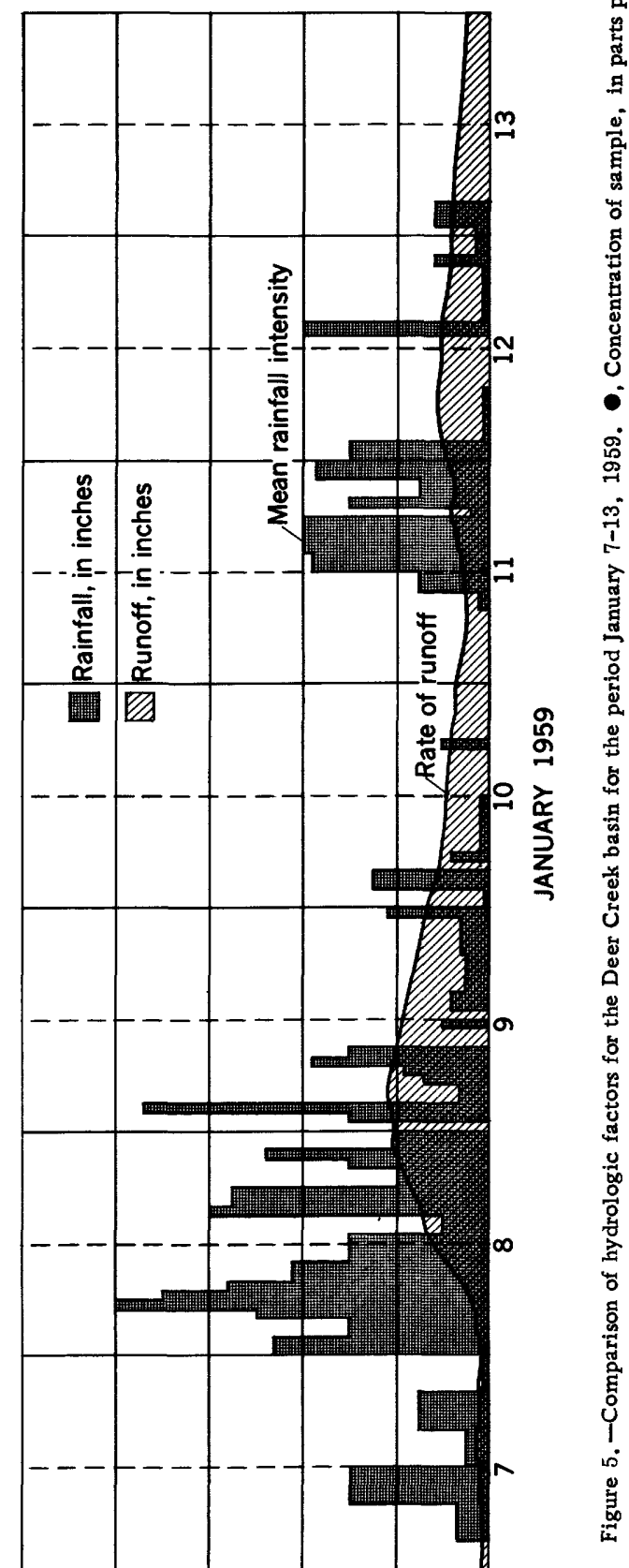
period of time in hours. The values obtained compared closely with values taken directly from the mass-rainfall graphs, and thus indicate that no great error was introduced. Losses by evaporation and transpiration can be neglected for the purposes of this study because these losses are small for freshet periods of short duration during the winter months.

Computation by the procedures described above shows that the total rainfall for the January 7-13 period was 10.46 inches; the runoff was 7.64 inches; and the remaining 2.82 inches was stored in surface depressions or as soil moisture. Thus a volume of water equaling 73 percent of the rainfall ran off before midnight on January 13. At this time, almost 21 hours after the last shower of the freshet period, the discharge of Deer Creek was still 20.6 cfs (cubic feet per second). This discharge decreased at an almost constant rate to $13.1 \mathrm{cfs}$ at 7:00 p.m. on January 15, when the next shower began. If the rate of decrease in discharge is assumed constant, after only about $3 \frac{1}{2}$ days after midnight on January 13, the discharge would fall to $5.8 \mathrm{cfs}$, the base-discharge at the beginning of the January 7-13 period. If all surface runoff had ceased by midnight January 13 , the 2.82 inches of water stored during the period would be depleted in less than 4 days even if evaporation and transpiration losses were ignored. The above analysis indicates that a volume of water equaling the rainfall for the period made its way to the surface water courses and left the basin in a short period of time; little was left to sustain flow during the late summer months. If the aquifer was not saturated before this freshet period, a low recharge rate and a low specific yield for the Burpee Formation in this vicinity are indicated.

The volume of water discharge (in cubic feet per second-hours per square mile) for any period of time (in hours) is represented by the area under the water-discharge graph in the upper half of figure 5. This amount of water was available for fluvial-sediment transport for that period. The area under the sediment discharge graph for the same period of time represents the suspendedsediment load (in pounds per square mile) that was transported during the period.
FLOW AND CONCENTRATION DURATION

For many water uses, it is desirable to know what percentage of time during a year various magnitudes of daily mean flow and suspended-sediment concentration will be exceeded. These values can be predicted with fair accuracy by the use of the frequency duration curves based on the data for the first 2 years of record (fig. 6). Inasmuch as long-term records at nearby Newport, Oreg., (12 miles northwest of the study area) indicate that rainfall during these years was slightly higher than normal, the rainfall in these basins was also probably higher than normal. Because the flows and concentrations are assumed to have been higher than normal also, the values predicted for a normal year by these curves should be slightly high. An example of a possible use of these curves would be to find what percentage of time the flow exceeds a known value at which salmon can move upstream to spawning beds. Assume that this value is 6.5 cfs for Flynn Creek. Use the flow duration curve for Flynn Creek to find where $6.5 \mathrm{cfs}$ on the ordinate intersects the curve and, by vertical projection to the abscissa, read 22. This figure is the percentage of time that a daily mean flow of $6.5 \mathrm{cfs}$ can be expected to be equalled or exceeded at the Flynn Creek gage. It might be desirable to know for hydrologic or aquatic studies what value of suspended-sediment concentration for Flynn Creek will be exceeded 50 percent of the time. To find this value, project the intersection of the 50 -percent line with the concentration duration curve for Flynn Creek horizontally to the ordinate, and read 2+ ppm (parts per million) the daily mean concentration that will be equalled or exceeded 50 percent of the time. The relationships given by these curves should not change greatly until the parameters are changed when logging operations begin.

\section{WATER TEMPERATURE}

The variation between the maximum and minimum water temperatures for the three streams during the 1959 and 1960 water years was only $22^{\circ} \mathrm{F}$, the maximum was $59^{\circ} \mathrm{F}$, and the minimum was $37^{\circ} \mathrm{F}$. The maximums for the three streams were identical at $59^{\circ} \mathrm{F}$, and the minimums ranged from $37^{\circ} \mathrm{F}$ for Needle 

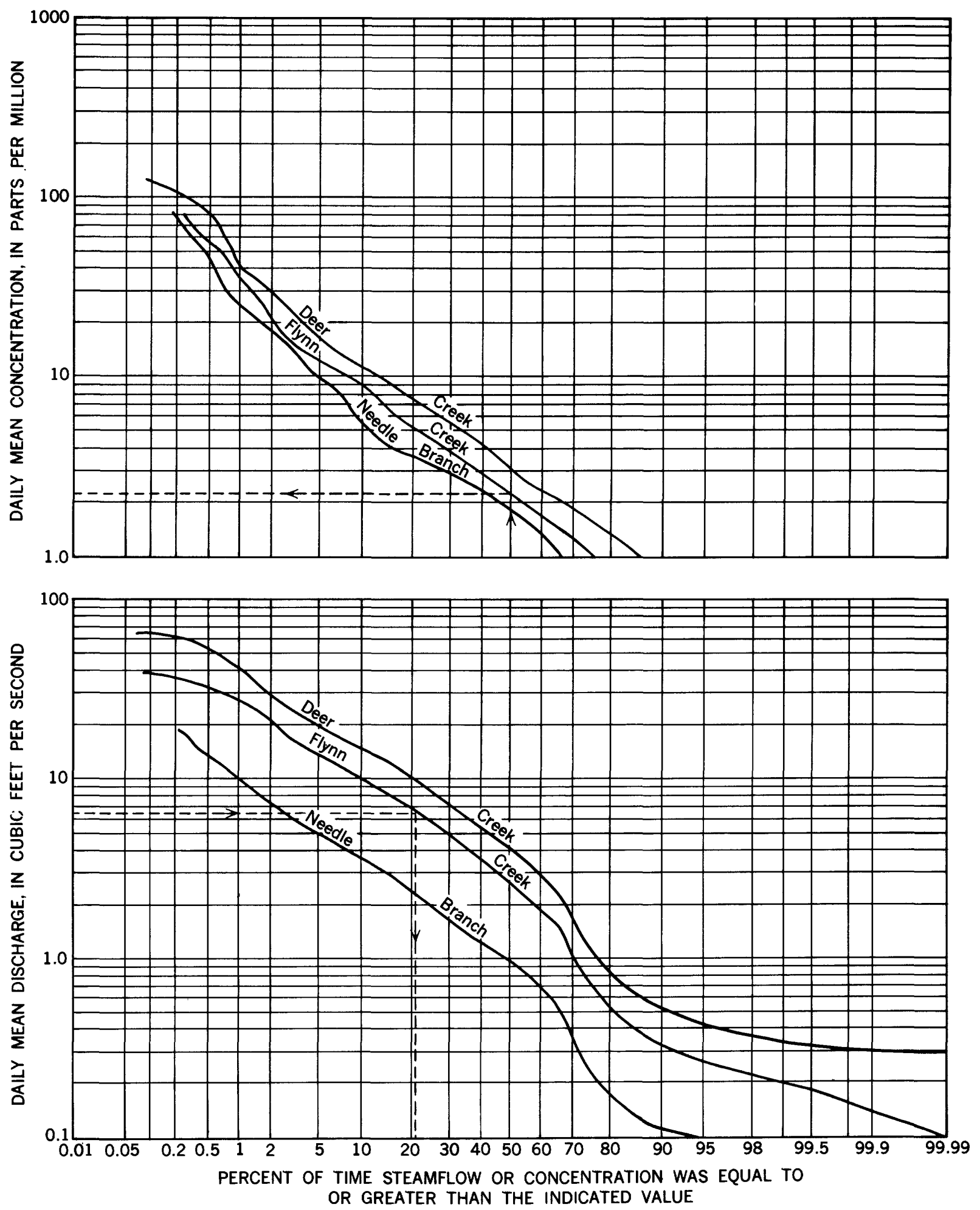

Figure 6. -Streamflow (bottom) and suspended-sediment concentration duration (top) curves for the streams (based on records for 1959 and 1960 water years). 
Branch, the smallest stream, to $40^{\circ} \mathrm{F}$ for Deer Creek, the largest stream. These streams are the greatest distance apart and have the greatest difference in average altitude. Table 3 gives a summary of average monthly maximum and minimum water temperatures.

The differences given above for streams indicate that the water temperatures of these streams vary little from stream to stream and from time to time. The effect of water temperature therefore can be disregarded when comparing sediment yields from these small forested basins during the prelogging period because the small differences shown for the basins would have little effect on fluvial-sediment transport (U.S. Inter-Agency Committee on Water Resources, 1957). The turbulence in these streams is more than sufficient to hold in suspension silt and clay particles which would otherwise be most affected by temperature differences.

\section{SUMMARY}

The rainfall, runoff, and sediment yield of the three basins are seasonal. A large proportion of the rainfall and runoff occur during the freshets of the October to May period. Almost all of the sediment discharge occurs during the relatively few days of freshet activity. As much as one-fourth of the annual sediment load may occur in 1 day, and over one-half may occur in the 10 days of greatest discharge.

For the 2 years of record, the annual precipitation, runoff, and suspended-sediment yield for each of the three forested drainage basins did not vary greatly. However, the suspended-sediment yield of the Deer Creek basin was nearly 2 times that of the Needle
Branch basin and nearly $1 \frac{1}{2}$ tinies that of the Flynn Creek basin.

A study of the January 7-13, 1959, freshet period in the Deer Creek basin showed that probably only a small part of the precipitation during freshet periods is stored as ground water. The study showed that a volume of water equal to the rainfall for the period left the basin in less than 4 days.

Water temperature during the 1959 and 1960 water years varied only $22^{\circ} \mathrm{F}$. The maximum variation between streams at any one time was only about $3^{\circ} \mathrm{F}$.

On the basis of records for the first 2 years of study, the Flynn Creek basin was a wise choice as the control or calibration basin. This drainage most nearly represents the average of the hydrologic conditions of the three study basins.

\section{LITERATURE CITED}

Chapman, D. W., Corliss, J. F., Phillips, R.W., and Demory, R. L., 1961, Alsea watershed study: Oregon Agr. Exp. Sta. Misc. Paper 110, 52 p., Corvallis.

Court, Arnold, 1960, Reliability of hourly precipitation data: Jour. Geophys. Research, v. 65 , no. 12 , p. $4017-4024$.

Mead, D. W., 1950, Hydrology: New York and London, McGraw-Hill Book Co. p. 195-208.

U.S. Inter-Agency Committee on Water Resources, Subcommittee on Sedimentation 1957, Some fundamentals of particle size analysis: Rept. 12, p. 24.

Vokes, H. E., Norbisrath, H., and Snavely, P. D., Jr., 1949, Geology of the NewportWaldport area, Lincoln County, Oregon: U.S. Geol. .Survey Oil and Gas Inv. Prelim. Map OM-88. 